\title{
An Insight from Undergraduate Medical Students of Khyber Pakhtunkhwa.
}

\footnotetext{
1. MBBS, M.Phil (Anatomy), MHPE Assistant Professor of Anatomy Rehman College of Dentistry Peshawar.

2. BDS, MPH, MHPE Assistant Professor Institute of Health Professions Education \& Research, Khyber Medical University Peshawar.

3. MBBS, M.Phil, MHPE Assitant Professor of Physiology Peshawar Medical College, Peshawar.

4. MBBS, MHPE

Senior Lecturer

Bahria University Medical College Karachi
}

Correspondence Address: Dr. Brekhna Jamil

Institute of Health Professions

Education \& Research

Khyber Medical University, Peshawar. drbrekhna.iph@kmu.edu.pk

Article received on: 06/07/2020

Accepted for publication: 10/09/2020

\begin{abstract}
Nazish Waheed ${ }^{1}$, Brekhna Jamil'2, Robina Usman ${ }^{3}$, Humera Waqar ${ }^{4}$
ABSTRACT... Objective: This study was conducted to evaluate the knowledge and attitude of undergraduate medical students toward research. Study Design: Cross sectional study. Setting: Private Medical Colleges of Khyber Pakhtunkhwa. Period: November 2018 to July 2019. Material \& Methods: A total of 938 final year medical students participated in the study. A validated self administered questionnaire was used for the collection of data. The student's perception was assessed through questionnaire based on 5-point Likert scale. For the assessment of knowledge MCQs were marked as 1 in case of correct answer and 0 in case of incorrect answer. Results: Out of 1300 students, 938 returned the questionnaire resulting in a $74 \%$ response rate. $481(51 \%)$ participants were male and $457(49 \%)$ were females. The participants had a mean knowledge score of 6.103 out of a total of 15 questions and mean attitude score of 76.29. Conclusion: This study concludes a low knowledge score coupled with a positive attitude of doing research. More attention must be placed on these parameters in the curriculum to improve student knowledge in health research.
\end{abstract}

Keywords: $\quad$ Attitude, Knowledge, Medical Student, Research, Undergraduate.

Article Citation: Waheed N, Jamil B, Usman R, Waqar H. An Insight from Undergraduate Medical Students of Khyber Pakhtunkhwa. Professional Med J 2021; 28(3):399-406. https://doi.org/10.29309/TPMJ/2021.28.03.5465

\section{INTRODUCTION}

Research is regarded as keystone of evidence based medicine. Research transforms most recent knowledge to tools that help in disease prevention and control. Novel research trials bring about change in medical practice. It provides evidence for providing best therapeutic option for patients by the latest available data. ${ }^{1}$

Research plays a crucial role in providing health care. It plays an important part in progress and prosperity of a country. ${ }^{2}$ The developing countries like Pakistan lag behind in research and it is estimated that it has only 208 researchers per million of population compared to developed countries where there are 4526 researchers per million of population. ${ }^{3}$ This clearly identifies the need of having good researchers in the community who can play a critical role in progress of scientific research. They can bring about the change needed in the health care system of a country. ${ }^{3}$
A researcher should have an inquisitive mind and motivation to do research. Involvement in research requires knowledge, scholarly approach, dedication and hard work on behalf of researcher. These qualities can be inculcated by an early exposure to research at least at undergraduate level and providing sufficient knowledge to develop the attitude to do best possible research. ${ }^{4}$

Undergraduate research is being conducted in few medical colleges of Pakistan. In Khyber Pakhtunkhwa, only few medical colleges have adapted to this positive change. The research culture is welcomed in a handful of universities mainly influenced by their own faculty who are either true medical scientists or do research to survive in the list of vast growing medical colleges. ${ }^{5-8}$ There is a gap of authentic literature representing the public as well as private sector medical institutes of KPK. This study was planned to highlight the factors related to medical research amongst the young medical minds of the city. 
It was intended to observe the involvement in research, of final year medical students of public as well as private sector medical colleges of KPK falling under the umbrella of KMU, Pakistan and to identify the factors influencing their interest in medical research.

\section{MATERIAL \& METHODS}

A Cross sectional study was carried out on final year M.B.B.S students at public and private medical colleges, affiliated with Khyber Medical University, Peshawar. This study was conducted during November 2018 to July 2019. A questionnaire based on five point Likert scale was developed to assess the perceptions regarding research. The questionnaire was adopted from two studies ${ }^{6,9}$ and it was modified according to the local setting and requirements for this study. The face and content validity was established through five experts including two experts in health research and three medical educationists. The MCQs were developed for assessing knowledge.

Ethical approval was granted from ethical board of Khyber Medical University (DIR/KMU-EB/ $\mathrm{KA} / 000505)$. The permission was also granted from the Principal/Dean of respective colleges. After taking permission the process of data collection started. The purpose and benefits of study were explained to the participants. A written informed consent was obtained. Each participant received an information sheet and a consent form.

Data were analyzed using SPSS 21 . Frequencies and percentages were calculated for each item. Mean score was calculated for perception on each question as highly satisfied (greater than 4), moderately satisfied (3-4) not satisfied (less than 2.5).

\section{RESULTS}

The questionnaire was filled out by 938 students of different medical colleges, with $74 \%$ response rate, achieved in three rounds. Out of 938 participants $481(51 \%)$ were male and $457(49 \%)$ were females. $651(69 \%)$ belonged to urban areas while $287(31 \%)$ belonged to rural area. Table-I and II shows that the students who had membership of some research body and who had previous publications. Table-III and TableIV shows the attitude and perceived barriers in conducting research.

Table-V describes the knowledge assessment score which is higher for female students as compared to male students and this difference was statistically significant ( $p$-value. 000). Attitude score was slightly higher in males as compared to female students but it was not statistically significant ( $p$-value. 261).

\begin{tabular}{|c|c|c|}
\hline \multirow{2}{*}{$\begin{array}{c}\text { Member of } \\
\text { Research Body }\end{array}$} & \multicolumn{2}{|c|}{ Frequency } \\
\hline & Male & Female \\
\hline No & 301 & 279 \\
\hline Yes & 180 & 178 \\
\hline Total & \multicolumn{2}{|c|}{938} \\
\hline \multicolumn{3}{|c|}{ Table-I. Students affiliated to research bodies } \\
\hline \multirow{2}{*}{$\begin{array}{l}\text { Previous } \\
\text { Publication }\end{array}$} & \multicolumn{2}{|c|}{ Frequency } \\
\hline & Male & Female \\
\hline No & 409 & 369 \\
\hline Yes & 72 & 88 \\
\hline Total & \multicolumn{2}{|c|}{938} \\
\hline
\end{tabular}

\section{DISCUSSION}

Evidence based medicine is need of time which allows physicians to provide best care to the patients on the basis of latest evidence available. ${ }^{3}$ A Physician can only understand the process of evidence collection if he is aware of research methodology. This can be achieved by introducing medical students to research at undergraduate level. ${ }^{10,11}$ This study not only assessed the knowledge of undergraduate students regarding research but also highlighted interest of students towards research and identified the challenges faced by the students while pursuing research.

It was observed that males and females equally participated in publication and almost same number were affiliated to some research body but the overall involvement of students was very less and very few numbers of students had research publications or were member of research body as can be seen in Table-I and Table-II. 


\begin{tabular}{|c|c|c|c|c|c|c|c|}
\hline $\begin{array}{l}\text { S } \\
\text { No }\end{array}$ & Attitude towards scientific research & $\begin{array}{l}5 \text { Strongly } \\
\text { agree }\end{array}$ & 4 Agree & 3 Neutral & 2 Disagree & $\begin{array}{l}1 \text { Strongly } \\
\text { Disagree }\end{array}$ & Mean \\
\hline 1 & $\begin{array}{l}\text { Scientific research gives us better } \\
\text { understanding of the world }\end{array}$ & 60 & 32 & 5 & 1 & 2 & 4.4 \\
\hline 2 & $\begin{array}{c}\text { Scientific approach facilitates better } \\
\text { understanding of problems }\end{array}$ & 40 & 48 & 10 & 1 & 1 & 4.3 \\
\hline 3 & $\begin{array}{l}\text { The knowledge of scientific research } \\
\text { methodology is essential for obtaining } \\
\text { accurate and objective data for } \\
\text { scientific research }\end{array}$ & 37 & 44 & 17 & 2 & 1 & 4.3 \\
\hline 4 & $\begin{array}{l}\text { Conducting scientific research is } \\
\text { beneficial for evidence based decision } \\
\text { making in practical life }\end{array}$ & 35 & 44 & 16 & 4 & 1 & 4.1 \\
\hline 5 & $\begin{array}{l}\text { Every doctor must be familiar with } \\
\text { scientific research methodology }\end{array}$ & 41 & 34 & 18 & 4 & 2 & 4.1 \\
\hline 6 & $\begin{array}{l}\text { Research helps to change health } \\
\text { policies }\end{array}$ & 31 & 37 & 22 & 6 & 4 & 3.8 \\
\hline 7 & Research/statistic is dull and boring & 26 & 25 & 19 & 17 & 12 & 3.4 \\
\hline 8 & $\begin{array}{l}\text { Is Research helpful in promoting critical } \\
\text { thinking }\end{array}$ & 28 & 44 & 21 & 5 & 1 & 4 \\
\hline 9 & $\begin{array}{c}\text { Taking time off to do research is waste } \\
\text { of time }\end{array}$ & 15 & 19 & 22 & 25 & 20 & 2.8 \\
\hline 10 & $\begin{array}{l}\text { Having research publications can help } \\
\text { me in fellowship programs in the future }\end{array}$ & 34 & 35 & 23 & 6 & 2 & 3.9 \\
\hline 11 & $\begin{array}{l}\text { Undergraduate research conferences } \\
\text { can increase your interest in research }\end{array}$ & 33 & 32 & 23 & 8 & 3 & 4.1 \\
\hline 12 & $\begin{array}{c}\text { Medical students can design and } \\
\text { conduct research and write research } \\
\text { paper }\end{array}$ & 21 & 47 & 24 & 5 & 3 & 3.8 \\
\hline 13 & I wish to write a research paper & 31 & 33 & 21 & 8 & 6 & 3.9 \\
\hline 14 & $\begin{array}{l}\text { Are you interested to be involved in } \\
\text { research throughout your medical } \\
\text { career }\end{array}$ & 25 & 39 & 21 & 10 & 5 & 3.7 \\
\hline 15 & $\begin{array}{l}\text { Research must be made an } \\
\text { essential component of each year of } \\
\text { undergraduate medical curriculum }\end{array}$ & 22 & 35 & 21 & 14 & 8 & 3.6 \\
\hline 16 & $\begin{array}{l}\text { I am willing to conduct research based } \\
\text { on clinical problems }\end{array}$ & 33 & 33 & 22 & 8 & 3 & 3.8 \\
\hline 17 & $\begin{array}{l}\text { I am willing to conduct research based } \\
\text { on community problem }\end{array}$ & 25 & 34 & 23 & 10 & 8 & 3.5 \\
\hline 18 & $\begin{array}{l}\text { I tend to do laboratory studies related to } \\
\text { clinical practice }\end{array}$ & 30 & 33 & 24 & 9 & 3 & 3.8 \\
\hline 19 & I like reading scientific journals & 13 & 36 & 31 & 12 & 8 & 3.3 \\
\hline 20 & $\begin{array}{l}\text { I feel research should be done only at } \\
\text { postgraduate level }\end{array}$ & 20 & 22 & 27 & 19 & 11 & 3.2 \\
\hline
\end{tabular}

Table-III. Mean scores of students' Attitude towards research. 


\begin{tabular}{|c|c|c|c|c|c|c|c|}
\hline $\begin{array}{l}\text { S. } \\
\text { No }\end{array}$ & Perceived Barriers Towards Research & $\begin{array}{c}5 \\
\text { Strongly } \\
\text { agree }\end{array}$ & $\begin{array}{c}4 \\
\text { Agree }\end{array}$ & $\begin{array}{c}3 \\
\text { Neutral }\end{array}$ & $\begin{array}{c}2 \\
\text { Disagree }\end{array}$ & $\begin{array}{c}1 \\
\text { Strongly } \\
\text { Disagree }\end{array}$ & Mean \\
\hline 1. & $\begin{array}{l}\text { Lack of adequate time due to educational } \\
\text { activities and high burden of studies }\end{array}$ & 53 & 34 & 9 & 2 & 2 & 4.3 \\
\hline 2. & Lack of proper training to conduct research & 48 & 38 & 10 & 3 & 1 & 4.4 \\
\hline 3. & Lack of familiarity with research methodology & 46 & 34 & 14 & 4 & 1 & 4.3 \\
\hline 4. & Lack of familiarity with statistical procedures & 44 & 33 & 15 & 5 & 3 & 4.4 \\
\hline 5. & Lack of skills for scientific paper writing & 42 & 36 & 14 & 5 & 2 & 4 \\
\hline 6. & Lack of interest in research & 23 & 34 & 23 & 13 & 6 & 3.5 \\
\hline 7. & Lack of good research ideas & 20 & 35 & 22 & 18 & 6 & 3.4 \\
\hline 8. & $\begin{array}{c}\text { Inaccessibility to medical and other electronically } \\
\text { relevant databases }\end{array}$ & 26 & 35 & 23 & 9 & 6 & 3.9 \\
\hline 9. & $\begin{array}{l}\text { Difficult administrative protocols to start a } \\
\text { research project }\end{array}$ & 34 & 35 & 21 & 8 & 3 & 3.9 \\
\hline 10. & $\begin{array}{l}\text { Difficulty in data collection due to ignorance of } \\
\text { target population }\end{array}$ & 34 & 37 & 18 & 7 & 4 & 3.9 \\
\hline 11. & $\begin{array}{l}\text { Difficult to get data due to improper } \\
\text { documentation/record keeping of data }\end{array}$ & 32 & 36 & 20 & 8 & 2 & 4 \\
\hline 12. & $\begin{array}{l}\text { Security issue during data collection procedures } \\
\text { from the community }\end{array}$ & 22 & 36 & 20 & 15 & 7 & 3.5 \\
\hline 13. & No cooperation from faculty & 28 & 30 & 25 & 12 & 4 & 3.7 \\
\hline 14. & $\begin{array}{l}\text { No cooperation between students for conducting } \\
\text { research in groups }\end{array}$ & 32 & 37 & 20 & 7 & 4 & 3.8 \\
\hline 15. & Inappropriate guidance for paper writing & 34 & 32 & 22 & 9 & 3 & 3.9 \\
\hline 16. & $\begin{array}{l}\text { Faculty do not provide opportunity to select } \\
\text { topic of choice }\end{array}$ & 21 & 33 & 25 & 16 & 4 & 3.7 \\
\hline 17. & Lack of a research department in the institute & 26 & 30 & 20 & 15 & 8 & 3.6 \\
\hline 18. & Lack of faculty training in health research & 24 & 36 & 23 & 12 & 5 & 3.6 \\
\hline 19. & $\begin{array}{l}\text { I do not get appropriate or sufficient consultation } \\
\text { before drafting research proposals }\end{array}$ & 26 & 32 & 28 & 11 & 3 & 3.6 \\
\hline 20. & No reward on completion of research project & 46 & 30 & 17 & 8 & 1 & 4.2 \\
\hline 21. & No funding available & 46 & 30 & 17 & 6 & 2 & 4.2 \\
\hline 22. & $\begin{array}{l}\text { Difficult to do research due to Personal } \\
\text { economic \& financial problems }\end{array}$ & 25 & 35 & 25 & 10 & 4 & 3.7 \\
\hline 23. & I prefer to use the free time to do other task & 30 & 30 & 21 & 11 & 8 & 3.6 \\
\hline
\end{tabular}

Table-IV. Mean scores of students' perceived barriers towards research. 


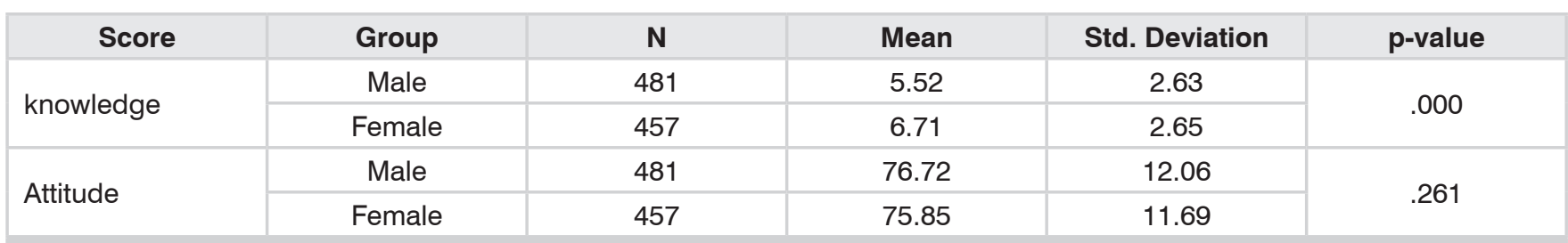

Table-V. Difference in mean scores for male and female students towards knowledge and attitude about research.

The similar findings were also observed in various studies that males are more actively involved in research publications. ${ }^{12-15}$

While assessing the knowledge a score of $50 \%$ or above was observed in 5 out of 15 questions. This is similar to a study that also reported a poor knowledge of students less than 37\% for physician in training and $49 \%$ for undergraduate students towards research ${ }^{6}$ and to a study with similar questionnaire among first year Croatian medical students where the knowledge score observed was $43 \%{ }^{16}$ The knowledge of students regarding sampling technique was $78 \%$ which is very good and is even better then postgraduate medical students. ${ }^{6}$

Attitude of students towards research can play a crucial role in their involvement in research; a negative attitude can hinder learning while a positive attitude and involvement in research can improve the learning process in undergraduate as well as postgraduate life. ${ }^{17}$ Attitude of students towards research was recorded by 20 close ended questions marked by Likert scale.80\% students agreed that scientific research not only improves the standards of health care but also promotes research activities in health professionals, while $72 \%$ students agreed that research improves critical thinking and showed a positive attitude towards conducting research. The study findings are similar to various studies. ${ }^{18-22}$ A very low response rate $46 \%$ was observed when students were asked about their aptitude to read scientific journals where as in a study it is reported that $50 \%$ of final year medical students were in a habit of reading scientific journals. ${ }^{23}$

Although awareness to getting involved in undergraduate research is increasing but still there are barriers to pursue research in its true zeal and spirit. These barriers can be in form of lack of knowledge lack of resources or lack of cooperation from faculty and community. $87 \%$ students considered lack of adequate time to be a barrier to participate in research activities (Table-IV). These findings are also reported by many studies done on undergraduate students in Pakistan as well as in different parts of world like India, Malaysia, Egypt, Czech Republic and Saudia where overburden of curricular activities act as a hindrance to pursue research. ${ }^{23-26} 75 \%$ of students agreed to their lack of familiarity to conducting research, writing research paper and understanding of statistical procedures. This can be improved by engaging students into regular workshops at undergraduate level and inculcating research curriculum into undergraduate course as has been done in many countries of the world. ${ }^{27,28}$ Another suggestion presented by Aziz $\mathrm{K}$ et.al is providing some extra time to students in their timetable to carry on research..$^{29} 58 \%$ students were of the view that no proper guidance were provided to them to draft a research proposal and conduct research. Similarly this study identified that $66 \%$ students were of the view that no guidance was provided by the faculty to write a research paper. This can be due to lack of faculty training in research as is identified in several studies where competent faculty is considered important for involvement of students in research similar to the findings in this study where $60 \%$ students are of the same view. ${ }^{30}$ Another factor that $76 \%$ of students found to be a contributing cause of a decline in research involvement was lack of acknowledgement and reward on completion of a research project. Similar findings are reported by Htoo et.al and Siemens et.al where 56 and $62 \%$ students considered lack of reward as a barrier to research activities. ${ }^{31}$

This research provides quantitative data about the research attitude of undergraduate medical 
students highlighting the existing knowledge and giving an insight to the attitude of student. It also draws attention to the difficulties that are hindering the progress of students to excel in the field of research. The strength of the study is that it covers all the government as well as the private medical colleges that come under the jurisdiction of Khyber Medical University thus providing information about students belonging to all areas and to different mental capabilities. The weakness of the study can be that it provides no comparison of data to medical colleges in other provinces of Pakistan. Still it provides a ground to other researchers to conduct studies at a large scale and compare it to the findings of this study.

\section{CONCLUSION}

Students are interested to conduct research to improve knowledge required to facilitate evidence based medicine in the clinical years to come. Students are confident that if provided a chance they can successfully conduct a research project and write a research paper. They think that they have the potential to generate a research question and work on it if provided proper mentoring.

Looking into these issues and solving the problems before including research into medical education will not only help the students but will be beneficial for the institutes as well and if properly addressed will help in producing researchers that can produce quality research.

Copyright $(10$ Sep, 2020.

\section{REFERENCES}

1. Dagher MM, Atieh JA, Soubra MK, Khoury SJ, Tamim $\mathrm{H}$, Kaafarani BR. Medical Research Volunteer Program (MRVP): innovative program promoting undergraduate research in the medical field. BMC medical education. 2016;16(1):160. doi: 10.1186/ s12909-016-0670-9.

2. Imafuku R, Saiki T, Kawakami C, Suzuki Y. How do students' perceptions of research and approaches to learning change in undergraduate research? International journal of medical education. 2015;6:47. doi: 10.5116/ijme.5523.2b9e.

3. Aslam F, Shakir M, Qayyum MA. Why medical students are crucial to the future of research in South Asia. PLoS medicine. 2005;2(11):e322. https://doi. org/10.1371/journal.pmed.0020322
4. Toledo-Pereyra LH. Ten qualities of a good researcher. Journal of Investigative Surgery. 2012;25(4):201-2. https://doi.org/10.3109/08941939.2012.701543

5. Sabzwari S, Kauser S, Khuwaja AK. Experiences, attitudes and barriers towards research amongst junior faculty of Pakistani medical universities. BMC medical education. 2009;9(1):68. DOI: 10.1186/14726920-9-68

6. Khan $\mathrm{H}$, Khan $\mathrm{S}$, Iqbal $\mathrm{A}$. Knowledge, attitudes and practices around health research: the perspective of physicians-in-training in Pakistan. BMC medical education. 2009;9(1):46. doi:10.1186/1472-6920-9-46

7. Khan H, Khawaja MR, Waheed A, Rauf MA, Fatmi Z. Knowledge and attitudes about health research amongst a group of Pakistani medical students. BMC medical education. 2006;6(1):54. doi:10.1186/14726920-6-54

8. Ejaz K, Shamim MS, Shamim MS, Hussain SA. Involvement of medical students and fresh medical graduates of Karachi, Pakistan in research. Journal of the Pakistan Medical Association. 2011;61(2):115.

9. Amin TT, Kaliyadan F, Al Qattan EA, Al Majed MH, Al Khanjaf HS, Mirza M. Knowledge, attitudes and barriers related to participation of medical students in research in three Arab Universities. Educ Med J. 2012;4(1):47-55.

10. Althubaiti A. Undergraduate Medical Research Programme: A Cross-Sectional Study of Students' Satisfactions, Perceived Challenges, and Attitudes. Global journal of health science. 2015;7(5):117. doi:10.5539/gjhs.v7n5p117

11. Moraes DW, Jotz M, Menegazzo WR, Menegazzo MS, Veloso S, Machry MC, et al. Interest in research among medical students: Challenges for the undergraduate education. Revista da Associação Médica Brasileira. 2016;62(7):652-8. DOI: 10.1590/1806-9282.62.07.652

12. Shah SMM, Sohail M, Ahmad KM, Imtiaz F, Iftikhar S. Grooming future physician-scientists: evaluating the impact of research motivations, practices, and perceived barriers towards the uptake of an academic career among medical students. Cureus. 2017;9(12). DOI: 10.7759/cureus.1991

13. Amgad M, Tsui MMK, Liptrott SJ, Shash E. Medical student research: an integrated mixed-methods systematic review and meta-analysis. PLoS one. 2015;10(6):e0127470. DOI: 10.1371/journal. pone. 0127470 
14. Guelich JM, Singer BH, Castro MC, Rosenberg LE. A gender gap in the next generation of physicianscientists: medical student interest and participation in research. Journal of Investigative Medicine. 2002;50(6):412-8. DOI: 10.1136/jim-50-06-01

15. Lloyd T, Phillips BR, Aber RC. Factors that influence doctors' participation in clinical research. Medical education. 2004;38(8):848 51. DOI: 10.1111/ j.13652929.2004.01895.x

16. Vodopivec I, Vujaklija A, Hrabak M, Lukic I, Marusic A, Marusic M. Knowledge about and attitude towards science of first year medical students. Croatian medical journal. 2002;43(1):58-62.

17. Burgoyne LN, O'Flynn S, Boylan GB. Undergraduate medical research: the student perspective. Medical education online. 2010;15(1):5212. DOI: 10.3402/meo. v15i0.5212

18. AlGhamdi KM, Moussa NA, AIEssa DS, AlOthimeen $\mathrm{N}$, Al-Saud AS. Perceptions, attitudes and practices toward research among senior medical students. Saudi Pharmaceutical Journal. 2014;22(2):113-7. DOI: 10.1016/j.jsps.2013.02.006

19. Soe HHK, Than NN, Lwin H, Htay MNNN, Phyu KL, Abas AL. Knowledge, attitudes, and barriers toward research: The perspectives of undergraduate medical and dental students. Journal of education and health promotion. 2018;7. DOI: 10.4103/jehp. jehp_61_17

20. Frishman WH. Student research projects and theses: should they be a requirement for medical school graduation? Heart disease (Hagerstown, Md). $2001 ; 3(3): 140-4$.

21. Jeelani W, Aslam SM, Elahi A. Current trends in undergraduate medical and dental research: a picture from Pakistan. Journal of Ayub Medical College Abbottabad. 2014;26(2):162-6.

22. Houlden RL, Raja JB, Collier CP, Clark AF, Waugh JM. Medical students' perceptions of an undergraduate research elective. Medical teacher. 2004;26(7):659-61. DOI: $10.1080 / 01421590400019542$
23. Algra A, Dekker F. The use of medical journals by medical students. Which medical journals are read? Nederlands tijdschrift voor geneeskunde. 2015; 159:A8850-A.

24. Anbari Z, Mohammadbeigi A, Jadidi R. Barriers and challenges in researches by Iranian students of medical universities. Perspectives in clinical research. 2015;6(2):98. DOI: 10.4103/2229-3485.154009

25. Mostafa S, Khashab S, Fouaad A, Abdel MB, Waly A. Engaging undergraduate medical students in health research: students' perceptions and attitudes, and evaluation of a training workshop on research methodology. The Journal of the Egyptian Public Health Association. 2006;81(1-2):99-118.

26. Mokry J, Mokra D. Opinions of medical students on the pre-graduate scientific activities-how to improve the situation? Biomedical Papers of the Medical Faculty of Palacky University in Olomouc. 2007;151(1). DOI: 10.5507/bp.2007.029

27. Chatterjee S, Adhikari A, Haldar D, Biswas P. Perception, awareness and practice of research-oriented medical education among undergraduate students of a medical college in Kolkata, West Bengal. The National medical journal of India. 2016;29(2):94.

28. Devi V, Abraham RR, Adiga A, Ramnarayan K, Kamath A. Fostering research skills in undergraduate medical students through Mentored Student Projects: Example from an Indian medical school. Kathmandu University Medical Journal. 2010;8(3):294-8. DOI: 10.3126/kumj.v8i3.6215

29. Aziz K, Sallam T, Ibrahim A, Sufian T. Improvement of research and biomedical publication. Saudi medical journal. 2004;25(10):1319.

30. Ibrahim Abushouk A, Nazmy Hatata A, Mahmoud Omran I, Mahmoud Youniss M, Fayez Elmansy K, Gad Meawad A. Attitudes and perceived barriers among medical students towards clinical research: A crosssectional study in an Egyptian medical school. Journal of Biomedical Education. 2016;2016. doi. org/10.1155/2016/5490575

31. Siemens DR, Punnen S, Wong J, Kanji N. A survey on the attitudes towards research in medical school. BMC medical education. 2010;10(1):4. DOI: 10.1186/1472-6920-10-4 


\begin{tabular}{|c|c|c|c|}
\hline \multicolumn{4}{|c|}{ AUTHORSHIP AND CONTRIBUTION DECLARATION } \\
\hline Sr. \# & Author(s) Full Name & Contribution to the paper & Author(s) Signature \\
\hline 1 & Nazish Waheed & $\begin{array}{l}\text { Conceived, designed, data } \\
\text { analysis, manuscript editing. }\end{array}$ & Ansy \\
\hline 2 & Brekhna Jamil & $\begin{array}{l}\text { Review, Final approval fo } \\
\text { manuscript. }\end{array}$ & Autinge \\
\hline 3 & Robina Usman & $\begin{array}{l}\text { Manuscript writing, data } \\
\text { analysis. }\end{array}$ & Robina \\
\hline 4 & Humera Waqar & Data analysis. & jomert \\
\hline
\end{tabular}

